\title{
Sperm characteristics as additional evidence of close relationship between Lebiasina and Piabucina (Characiformes: Lebiasinidae: Lebiasininae)
}

\author{
Júlio César de O. Santana ${ }^{1}$, André L. Netto-Ferreira ${ }^{2}$, Daniela Calcagnotto ${ }^{3}$ \\ and Irani Quagio-Grassiotto ${ }^{4}$
}

\begin{abstract}
Spermiogenesis and spermatozoa of representatives of the genera Lebiasina and Piabucina are described. Spermiogenesis is quite similar among all analyzed species of these genera and is identified as Type II. In this type of spermiogenesis, the flagellum of earliest spermatids lies lateral to the nucleus. A slight movement of the nucleus towards the centriolar complex is observed. In late spermatids, the nucleus slightly elongates towards the flagellum. The formation of two striated rootlets apparently occurs in early/intermediate spermatids. The spermatozoa of species of Lebiasina and Piabucina share (1) a dropshaped slightly elongated nucleus that is laterally positioned relative to the flagellum; (2) a superolateral centriolar complex; (3) two striated rootlets; (4) a basolateral midpiece; (5) oblong mitochondria and (6) a few spherical vesicles. The spermatic characteristics of Lebiasina and Piabucina indicate that spermiogenesis is a homologous process among all species of both genera examined to date and can be considered, along with the spermatozoa morphology, additional evidence indicating a close relationship between Lebiasina and Piabucina.
\end{abstract}

A espermiogênese e os espermatozoides de representantes dos gêneros Lebiasina e Piabucina são descritos. O processo de espermiogênese é muito semelhante entre todas as espécies analisadas, sendo descrita como do Tipo II. Nesta variação de espermiogênese o flagelo das espermátides iniciais localiza-se lateralmente ao núcleo. O núcleo movimenta-se ligeiramente sobre o complexo centriolar. Nas espermátides finais, o núcleo alonga-se ligeiramente em direção ao eixo flagelar. A formação de duas raízes estriadas ocorre nas espermátides iniciais/intermediárias. Os espermatozoides das espécies de Lebiasiana e Piabucina compartilham principalmente (1) o núcleo em forma de gota, lateralmente posicionado em relação ao eixo flagelar, e ligeiramente alongado em direção ao flagelo, (2) o complexo centriolar superolateral, (3) duas raízes estriadas surgindo a partir do centríolo distal, (4) peça intermediária basolateral, (5) mitocôndrias oblongas e (6) algumas vesículas esféricas. As características espermáticas de Lebiasina e Piabucina foram observadas comparativamente e permitem concluir que o processo de espermiogênese é homólogo em todas as espécies destes dois gêneros examinadas até o momento. Os espermatozoides e principalmente os dados de espermiogênese são apresentados aqui como evidências adicionais que indicam uma relação estreita entre os gêneros Lebiasina e Piabucina.

Key words: Ostariophysi, Neotropical Fish, Spermatozoa, Systematics, Ultrastructure.

\section{Introduction}

Members of the family Lebiasinidae are known from Costa Rica and Panama in Central America and all countries of South America except Chile. Most species of the family are found in quiet, clear, or black water streams from sea level to about 250 meters elevation. Some species of the Lebiasininae, on the other hand, occur to over 1000 meters elevation (Weitzman \&
Weitzman, 2003). The Lebiasinidae is divided into two subfamilies, the Lebiasininae and Pyrrhulininae. The Lebiasininae is currently composed of 26 valid species, traditionally allocated to two genera, Lebiasina and Piabucina. Lebiasina has been distinguished from Piabucina based on the lack of an adipose fin and by the cellular composition of the swim bladder wall in Lebiasina versus the presence of an adipose fin and a noncellular

${ }^{1}$ Universidade Estadual de Campinas (UNICAMP), Programa de Pós-Graduação em Biologia Celular e Estrutural, Prédio da PG-IB, Bloco O, Caixa Postal 6109, 13083-865 Campinas, SP, Brazil. juliosantanas@yahoo.com.br

${ }^{2}$ Museu de Zoologia da Universidade de São Paulo (MZUSP), Caixa Postal 42494, 04218-970 São Paulo, SP, Brazil. alnferreira@gmail.com ${ }^{3}$ Universidade de São Paulo (USP), Departamento de Genética e Biologia Evolutiva, Instituto de Biociências, Rua do Matão, 277, 05508900 São Paulo, SP, Brazil. dcalcag@terra.com.br

${ }^{4}$ Universidade Estadual Paulista "Júlio de Mesquita Filho" (UNESP), Instituto de Biociências, Departamento de Morfologia, Rubião Júnior, s/n, 18618-970 Botucatu, SP, Brazil. iraniqg@ibb.unesp.br 
composition of the swim bladder wall in Piabucina. Due to questions as to significance of the characters used to diagnose both genera, the validity of Piabucina has been repeatedly questioned by authors. A recent taxonomic review and study of interspecific relationships in the Lebiasininae performed by Netto-Ferreira (2010) attests to the monophyly of the subfamily; however, it retrieves both Lebiasina and Piabucina as polyphyletic, and therefore, requires the synonym of Piabucina with Lebiasina. Consequently, recently described species lacking the cellular swim bladder wall have been assigned to Lebiasina regardless of the presence versus absence of the adipose fin (Netto-Ferreira et al., 2011, Netto-Ferreira, 2012).

Evidence for a close relationship between Lebiasina and Piabucina is provided by modifications of a variety of body systems including osteology and external morphology. Recent studies have shown that reproductive characters also provide evidences for relationships among fish taxa (Santana et al., 2013). Above and beyond its descriptive significance per se, a better understanding of this type of data is of major interest owing to its potential as an additional source of characters for future phylogenetic inferences. The process of spermiogenesis and spermatozoa ultrastructure of representatives of the Lebiasininae is described herein and information from this character complex is discussed to highlight the question of the relationships within the Lebiasininae.

\section{Material and Methods}

Examined specimens belong to the Academy of Natural Sciences of Philadelphia (ANSP); Museo de Ciencias Naturales, Guanare (MCNG); Museo de Historia Natural La Salle (MHNLS); Museo de Historia Natural de la Universidad Nacional Mayor de San Marcos (MUSM); and Museu de Zoologia da Universidade de São Paulo (MZUSP). Descriptions of spermatic characteristics are based on analyses at the ultrastructural level of gametic cells from testis of adult males of Lebiasina aff. festae (MUSM 6530), L. bimaculata (MUSM 15931), L. erythrinoides (MCNG 41376), L. melanoguttata (MZUSP 99610), L. aff. uruyensis1 (MZUSP 109118), L. aff. uruyensis2 (MHNLS 14468), Piabucina boruca (ANSP 140657), P. elongata (ANSP 130567) and P. panamensis (ANSP 104137).

Preparation of specimens for observation of spermatic features. Testis of specimens, previously fixed in $4 \%$ formaldehyde and stored in $70 \%$ alcohol, were gradually rehydrated in a decreasing ethanol concentration to distilled water. Once rehydrated, the material was re-fixed overnight in $2 \%$ glutaraldehyde and $4 \%$ paraformaldehyde in $0.1 \mathrm{M} \mathrm{pH} 7.2$ Sorensen phosphate buffer. The samples were post-fixed in the dark for $2 \mathrm{~h}$ in $1 \%$ osmium tetroxide in the same buffer, stained in block with an aqueous solution of $5 \%$ uranyl acetate for $2 \mathrm{~h}$, dehydrated in acetone, embedded in araldite, and sectioned and stained with a saturated solution of uranyl acetate in $50 \%$ ethanol and lead citrate. Electron micrographs were obtained using a Tecnai ${ }^{\circledR}$ transmission electron microscope.

\section{Results}

Spermiogenesis in the Lebiasininae. Details of spermiogenesis are consistent across the species of the Lebiasininae included in this study; therefore we present a general description of the process for all species. In the earliest spermatids the nucleus is spherical, filled with diffuse chromatin and encircled by the cytoplasm containing organelles (Fig. 1a-b). The centriolar complex lies lateral to the nucleus (Fig. 1a). The proximal centriole is anterior and slightly oblique to the distal centriole (Fig. 1a). In the centriolar complex, two striated rootlets radiate from opposite sides of the distal centriole (Fig. 1b-inset). The distal centriole differentiates into the basal body and organizes the axoneme of the flagellum (Fig. 1a). The centriolar complex does not migrate towards the nucleus. The nucleus is slightly moved up to the centriolar complex and then turns back, leaving only a very little portion covering the centriolar complex (Figs. 1c-d). A slight double depression, the nuclear fossa, is formed in the nuclear outline at the level of the centriolar complex (Fig. 1c). The cytoplasm moves toward the flagellar axis giving rise to the midpiece (Fig. 1d). Since the distal centriole is anchored at the plasma membrane when the cytoplasm slides toward the flagellar axis, it consequently encircles the initial segment of the flagellum forming the cytoplasmic canal (Figs. 1c-d). Chromatin compaction advances and the nucleus slightly elongates towards the flagellar axis (Fig. 1d). The midpiece lies basolateral to the flagellum therefore being strongly asymmetric. A few oblong mitochondria and vesicles are present in the midpiece. In late spermatids the chromatin is highly condensed, thus filling the entire nucleus. No flagellar fins were observed (Fig. 1d).

Spermatozoa of Lebiasininae species. The nucleus of the spermatozoa of all species lies lateral to the flagellar axis and is drop-shaped, being slightly elongate toward the flagellum (Figs. 2a,d,g, 3a,d,g, 4a,d,g). The length of the nucleus measured in longitudinal $\mathrm{x}$ transverse axis was $1.7 \mathrm{x}$ $1.4 \mu \mathrm{m}$ in Lebiasina aff. festae, $1.9 \mu \mathrm{m} \times 1.1 \mu \mathrm{m}$ in $L$. bimaculata, $1.7 \times 1.1 \mu \mathrm{m}$ in $L$. erythrinoides, $2.0 \times 1.4 \mu \mathrm{m}$ in $L$. melanoguttata, $2.2 \times 1.5 \mu \mathrm{m}$ in $L$. aff. uruyensis $1,1.9 \times 1.3 \mu \mathrm{m}$ in $L$. aff. uruyensis $2,1.8 \times 1.3 \mu \mathrm{m}$ in Piabucina boruca, $2.1 \mathrm{x}$ $1.3 \mu \mathrm{m}$ in P. elongata, and $1.8 \times 1.3 \mu \mathrm{m}$ in P. panamensis. In the nuclear outline, the shallow double nuclear fossa and consequently also the centriolar complex have a superolateral position close to the tip of the nucleus (Figs. $2 \mathrm{a}, \mathrm{d}, \mathrm{g}, 3 \mathrm{a}, \mathrm{d}, \mathrm{g}, 4 \mathrm{a}, \mathrm{d}, \mathrm{g})$. The anterior end of the proximal centriole is partially inserted in the first depression of the nuclear fossa, but the distal centriole is excluded from the depression (Figs. 2a-inset, d-inset, g-inset, 3a,d,g, 4a,d,g). The proximal centriole lies anterior to the distal centriole (Figs. 2a-inset, d-inset, g-inset, 3a,d,g, 4a,d,g). The orientation of the proximal centriole is slightly oblique 

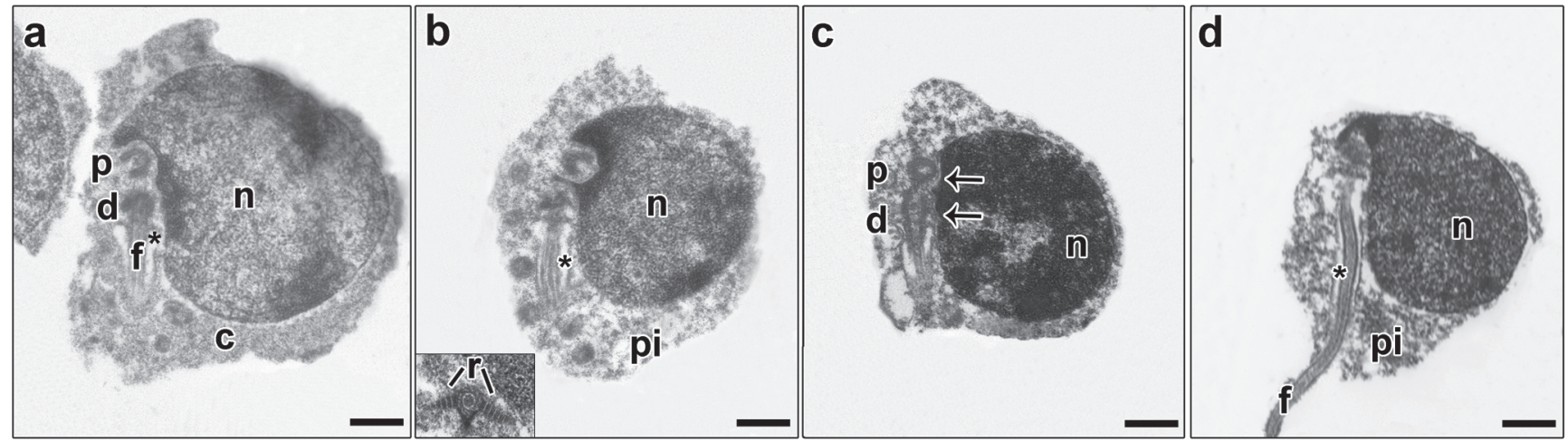

Fig. 1. Spermiogenesis process representative for Lebiasina and Piabucina. Figure subunits are longitudinal sections of spermatids corresponding to (a) Lebiasina aff. uruyensis1, (b) L. aff. uruyensis1, (c) Piabucina boruca, and (d) P. elongata. The flagellum is initially lateral to the nucleus. A slightly movement of the nucleus towards the flagellar axis is present. Consequently the centriolar complex and the nuclear fossa is superolateral. During spermiogenesis, the formation of two striated rootlets occurs on opposite sides of the distal centriole. c: cytoplasm, d: distal centriole, f: flagellum, n: nucleus, p: proximal centriole, pi: midpiece, r: striated rootlet, asterisk: cytoplasmic canal, arrow: nuclear fossa. $B a r=0.5 \mu \mathrm{m}$.

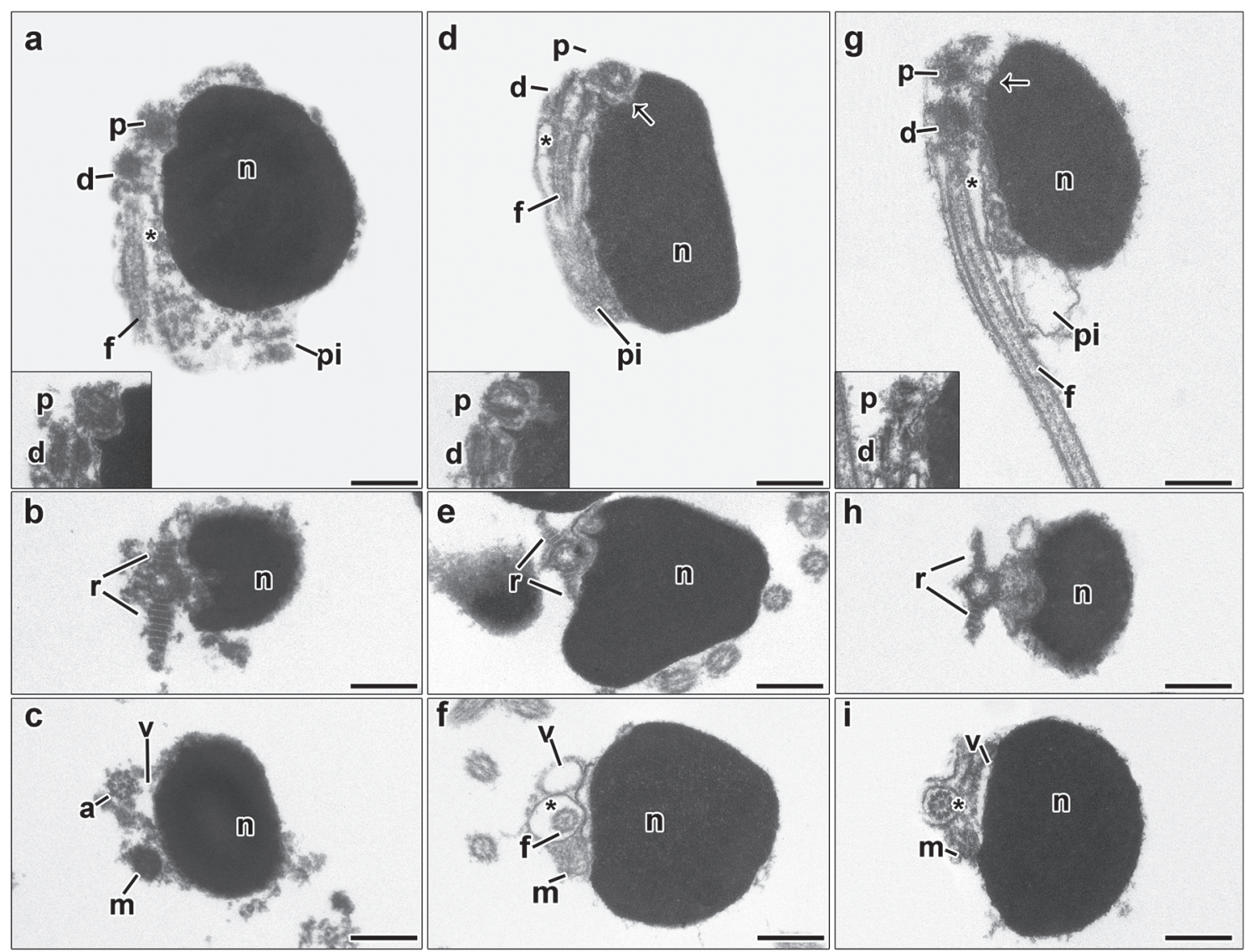

Fig. 2. Spermatozoon of Lebiasina aff. festae $(\mathbf{a}, \mathbf{b}, \mathbf{c})$, L. bimaculata $(\mathbf{d}, \mathbf{e}, \mathbf{f})$ and L. erythrinoides $(\mathbf{g}, \mathbf{h}, \mathbf{i})$. a, $\mathbf{d}, \mathbf{g}$ : longitudinal sections. $\mathbf{b}, \mathbf{c}, \mathbf{e}, \mathbf{f}, \mathbf{h}, \mathbf{i}$ : transverse sections from top to posterior region. The nucleus (n) of all species is drop-shaped and slightly elongated towards the flagellar axis. The flagellum (f) lies lateral to the nucleus. The centriolar complex (p, d) and nuclear fossa (arrow) is superolateral. Note the presence of the striated rootlets (r) on opposite sides of the distal centriole (d). The proximal centriole (p) is slightly oblique relative to the distal centriole (d) (a-inset, d-inset, g-inset). The cytoplasmic canal is present (asterisk). The midpiece (pi) is short, asymmetrical, and contains the oblong mitochondria (m) and vesicles (v). a: axoneme, d: distal centriole, f: flagellum, m: mitochondria, n: nucleus, p: proximal centriole, $r$ : striated rootlet, v: vesicle, asterisk: cytoplasmic canal, arrow: nuclear fossa. $\mathrm{Bar}=0.5 \mu \mathrm{m}$. 
relative to the distal centriole (Figs. 2a-inset, d-inset, g-inset, $3 \mathrm{a}, \mathrm{d}, \mathrm{g}, 4 \mathrm{a}, \mathrm{d}, \mathrm{g})$. In the centriolar complex, two striated rootlets irradiate from the opposite sides of the distal centriole (Figs. $2 \mathrm{~b}, \mathrm{e}, \mathrm{h}, 3 \mathrm{~b}, \mathrm{e}, \mathrm{h}, 4 \mathrm{~b}, \mathrm{e}, \mathrm{h})$. The short strongly asymmetric midpiece contains a cytoplasmic canal, an endomembrane system and a few oblong mitochondria (Figs. 2a,c,d,f,g,i, $3 \mathrm{a}, \mathrm{c}, \mathrm{d}, \mathrm{f}, \mathrm{g}, \mathrm{i}, 4 \mathrm{a}, \mathrm{c}, \mathrm{d}, \mathrm{f}, \mathrm{g}, \mathrm{i})$. Consequently, the midpiece is formed by a large region containing the endomembrane system with the mitochondria concentrated on the base of the nucleus, and a thin layer of cytoplasm without organelles (Figs. 2a,c,d,f,g,i, 3a,c,d,f,g,i, 4a,c,d,f,g,i). The endomembrane system is composed of a few spherical vesicles of small diameter (Figs. 2c,f,i, 3c,f,i, 4c,f,i). The flagellum contains the classic axoneme $(9+2)$ and lacks lateral membranous projections (Figs. 2a,d,g, 3a,d,g, 4a,d,g). A schematic representation summarizing the spermatozoa of Lebiasina and Piabucina is presented in Fig. 5.

\section{Discussion}

Lebiasina and Piabucina share the same characteristics of the process of spermiogenesis. This process involves a number of steps in the development of the male germ cells. These sequential steps may be unique in the process of spermiogenesis of the Lebiasininae, which is herein considered a variation of Type II spermiogenesis process. Type II spermiogenesis is characterized by the lateral flagellum relative to the nucleus of earliest spermatids and the absence of nuclear rotation (Mattei, 1970). Among the Lebiasininae, the flagellum is also lateral relative to the nucleus and there is no nuclear rotation. In addition, members of the Lebiasininae examined have an additional step involving nuclear elongation towards the flagellum. Type II spermiogenesis is usually considered simpler relative to Type I due to the fewer steps in the process. It has been demonstrated that knowledge of the process of

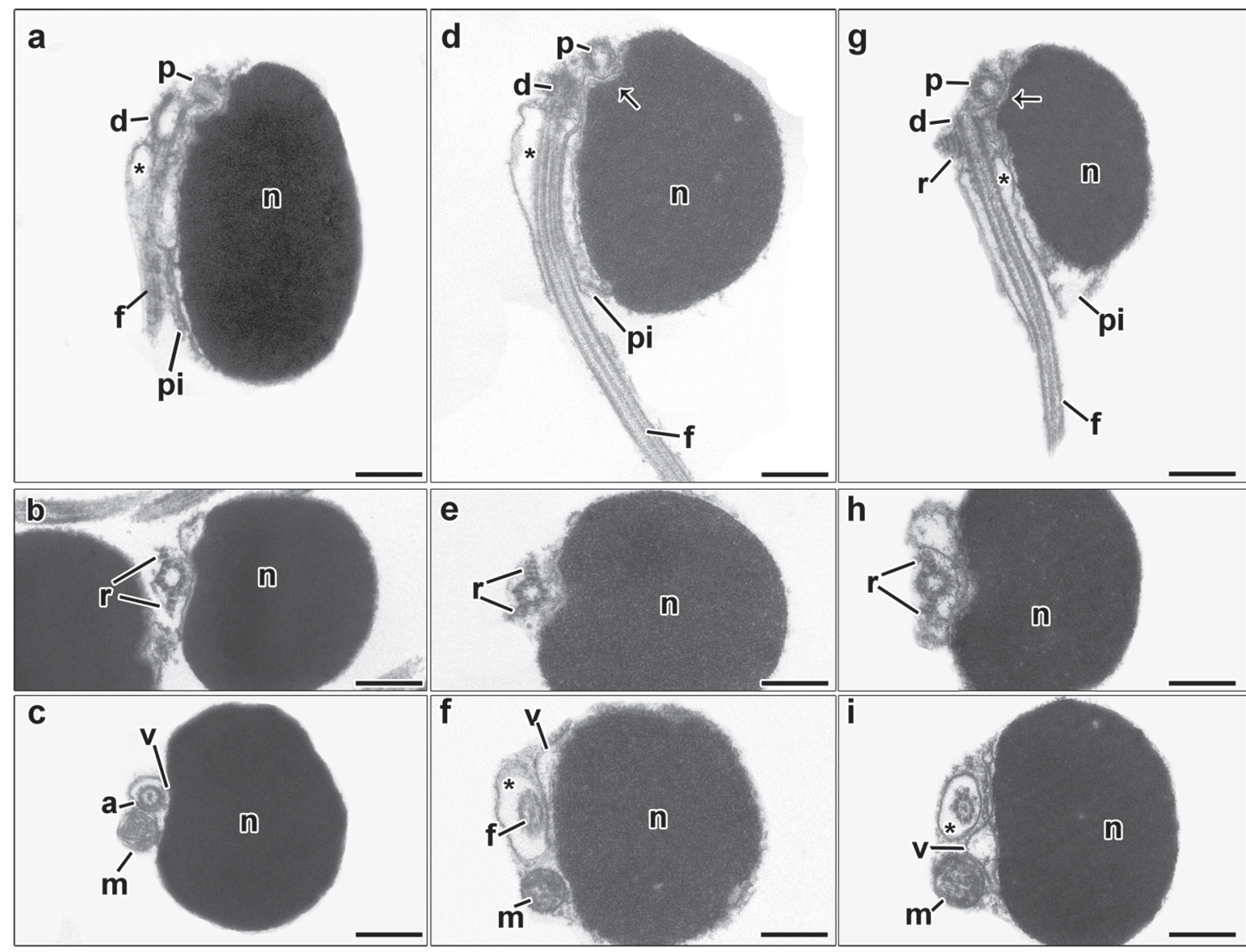

Fig. 3. Spermatozoon of Lebiasina melanoguttata $(\mathbf{a}, \mathbf{b}, \mathbf{c})$, L. aff. uruyensis $1(\mathbf{d}, \mathbf{e}, \mathbf{f})$ and $L$. aff. uruyensis $2(\mathbf{g}, \mathbf{h}, \mathbf{i})$. a, $\mathbf{d}, \mathbf{g}$ : longitudinal sections. $\mathbf{b}, \mathbf{c}, \mathbf{e}, \mathbf{f}, \mathbf{h}, \mathbf{i}$ : transverse sections from top to posterior region. The nucleus (n) of all species is dropshaped and slightly elongated towards the flagellar axis. The flagellum (f) lies lateral to the nucleus. The centriolar complex (p, d) and nuclear fossa (arrow) is superolateral. Note the presence of the striated rootlets (r) on opposite sides of the distal centriole (d). The proximal centriole (p) is slightly oblique relative to the distal centriole (d) (a-inset, d-inset, g-inset). The cytoplasmic canal is present (asterisk). The midpiece (pi) is short, asymmetrical, and contains the oblong mitochondria (m) and vesicles (v). a: axoneme, d: distal centriole, f: flagellum, m: mitochondria, n: nucleus, p: proximal centriole, r: striated rootlet, v: vesicle, asterisk: cytoplasmic canal, arrow: nuclear fossa. $\mathrm{Bar}=0.5 \mu \mathrm{m}$. 


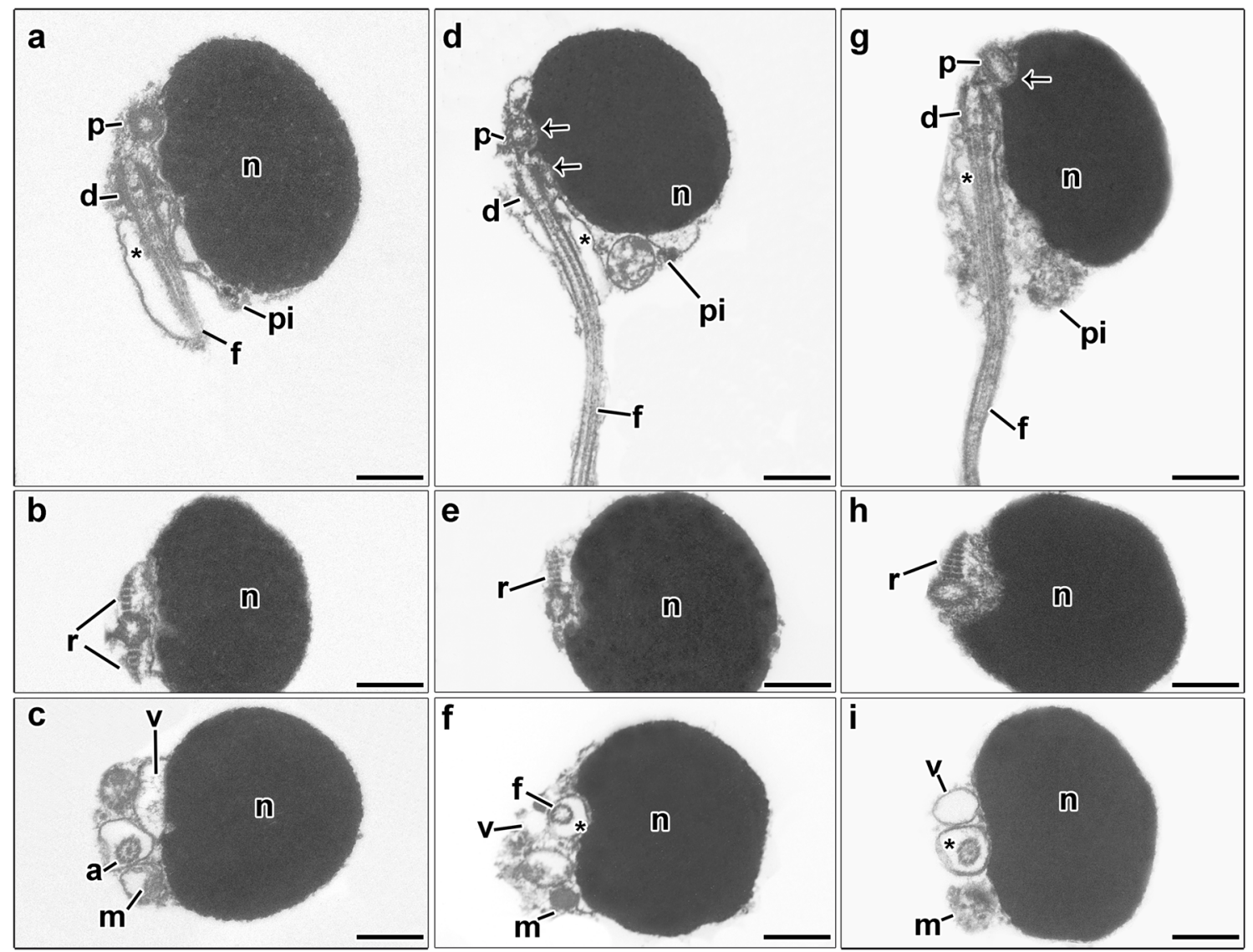

Fig. 4. Spermatozoon of Piabucina boruca (a, b, c), P. elongata (d, e, f) and P. panamensis (g, h, i). a, d, g: longitudinal sections. $\mathbf{b}, \mathbf{c}, \mathbf{e}, \mathbf{f}, \mathbf{h}, \mathbf{i}$ : transverse sections from top to posterior region. The nucleus (n) of all species is drop-shaped and slightly elongated towards the flagellar axis. The flagellum (f) lies lateral to the nucleus. The centriolar complex (p, d) and nuclear fossa (arrow) is superolateral. Note the presence of the striated rootlets (r) on opposite sides of the distal centriole (d). The proximal centriole ( $\mathrm{p}$ ) is slightly oblique relative to the distal centriole (d) (a-inset, d-inset, g-inset). The cytoplasmic canal is present (asterisk). The midpiece (pi) is short, asymmetrical, and contains the oblong mitochondria ( $\mathrm{m}$ ) and vesicles (v). a: axoneme, d: distal centriole, f: flagellum, m: mitochondria, n: nucleus, p: proximal centriole, r: striated rootlet, v: vesicle, asterisk: cytoplasmic canal, arrow: nuclear fossa. $\mathrm{Bar}=0.5 \mu \mathrm{m}$.

spermiogenesis is crucial for understanding the final shape of spermatozoa and to the proposition of homologies (BaicereSilva et al., 2011b).

Analysis of spermiogenesis becomes most important in cases in which the final shape of the spermatozoa is quite similar in different taxa. An example involves the spermatozoa of externally fertilizing species of the characid subfamily Stevardiinae, Boehlkea fredcuchoi, Bryconamericus exodon, Bryconacidnus ellisi, Ceratobranchia obtusirostris, Creagrutus meridionalis, Cyanocharax alburnus, Hemibrycon surinamensis, Knodus meridae, Odontostoechus lethostigmus, Piabina anhembi, and P. argentea (BaicereSilva et al., 2011b) and some species of Moenkhausia (M. costae, $M$. dichroura, $M$. grandisquamis, $M$. megalops, $M$. nigromarginata, $M$. tergimacula, and $M$. xinguensis- Santana et al., 2013). The spermatozoa of the aforementioned characids have an ovoid nucleus that is slightly elongated toward the flagellum, strongly eccentric, laterally positioned relative to the centriolar complex and has a short and asymmetric midpiece. Most of these features are very similar to those observed among the Lebiasininae. However, the spermiogenesis of the Stevardiinae is a variation between Type I (Mattei, 1970) and Type III (Quagio-Grassioto \& Oliveira, 2008) whereas that of species of Moenkhausia is a variation of Type III. Spermiogenesis of the Lebiasininae differs from that of the Stevardiinae and species of Moenkhausia primarily in (1) the lateral position of the flagellum relative to the nucleus in earliest spermatids ( $v s$. medial position); (2) the nuclear movement towards the centriolar complex (vs. nuclear rotation towards the flagellum); (3) and the absence of the migration of the centriolar complex towards the nucleus (vs. a presence at least in the Stevardiinae). The data presented 


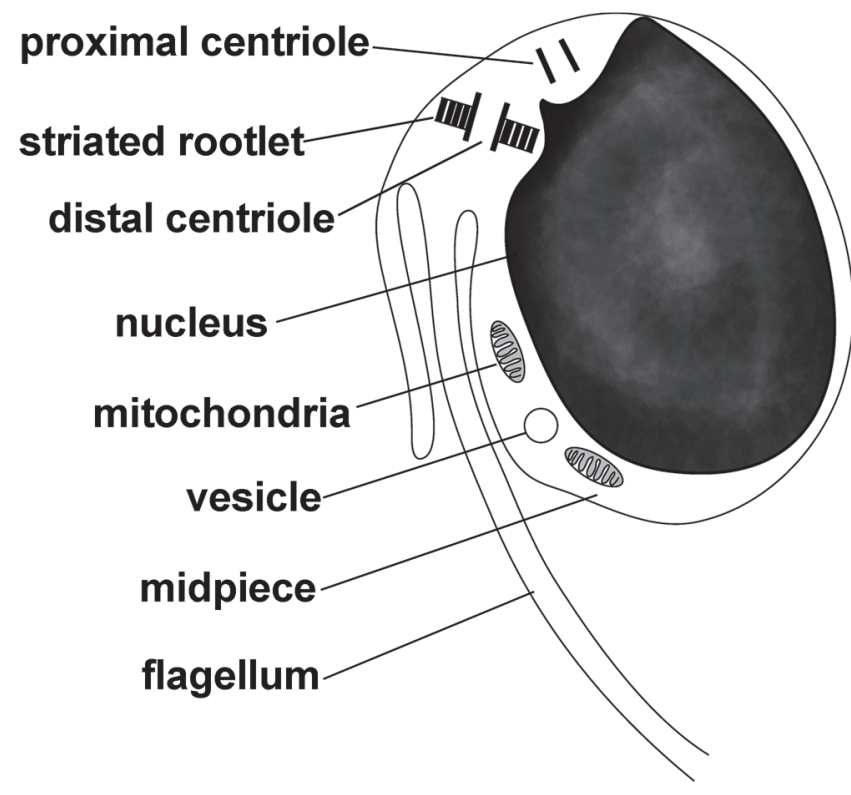

Fig. 5. Schematic representation of spermatozoa of Lebiasina and Piabucina. Both spermatozoa are very similar and share primarily the lateral nucleus, superolateral centriolar complex, striated rootlets, oblong mitochondria and some vesicles in the midpiece.

herein allow us to conclude that the process of spermiogenesis responsible for spermatozoa production varies considerably in both groups debated above, and therefore the spermatozoa morphology of the Lebiasininae is not homologous to that of the aforementioned externally fertilizing characid species.

The most common pattern of spermiogenesis in characiforms is Type I and its variations (see Burns et al., 2009 for a review). More restricted is the distribution of the Type II spermiogenesis pattern (Mattei, 1970) that has been observed so far solely in Acestrorhynchus falcatus (Acestrorhynchidae - Matos et al., 2000) and Pyrrhulina australis (Lebiasinidae Burns et al., 2009). The classification of all described types of spermiogenesis (I, II - Mattei, 1970; III - Quagio-Grassioto \& Oliveira, 2008) is based on the initial position of the flagellum relative to the nucleus and the presence versus absence of nuclear rotation towards the flagellum. The spermiogenesis in the Lebiasininae differs from that of Pyrrhulina australis in the presence versus absence of nuclear elongation. Therefore, in P. australis the spermiogenesis is considered to be a classical Type II. The additional step in the spermiogenesis of the lebiasinins is unique to date to this group of species. Considering that $P$. australis is a distally nested member of the Pyrrhulininae (Netto-Ferreira, 2010), that is the sister group of the Lebiasininae, it is likely that the Type II spermiogenesis is the general pattern across the family Lebiasinidae, and in this case, the presence of the additional step (i.e., the elongation of the nucleus) could be proposed as a derived character for the Lebiasininae.
All species of the examined Lebiasininae in this study have a similar structure of their spermatozoa. An important characteristic in addition to spermiogenesis that may further test to their close relationship is the presence of two striated rootlet structures combined with the other features described for the spermatozoa. The striated rootlets arise from opposite sides of the distal centriole and the rootlets function may be related to cell stabilization during flagellar swimming (Javonillo et al., 2007). Such striated rootlet structure is not unique to the Lebiasininae and may have originated independently several times in the Characiformes. A similar striated rootlet structure is found in other characiforms: the non-inseminating species Acestrorhynchus falcatus (Matos et al., 2000), and the inseminating species Brittanichthys axelrodi (Javonillo et al., 2007), Macropsobrycon uruguayanae (Oliveira et al., 2008) and Planaltina myersi (Ferreira et al., 2011). However, in those taxa the striated rootlets show different diameters and lengths relative to the members of the Lebiasininae studied in this analysis. Since the striated rootlets are absent in the spermatozoa of the Pyrrhulininae, and the family Erythrinidae (see Burns et al., 2009 for a review), this feature can also be considered an additional apomorphy defining the Lebiasininae.

Information from spermiogenesis and structure of the spermatozoa provides additional and new evidence to support a hypothesis of a close relationship among the species of the Lebiasininae. Comparably information were recently reported by Baicere-Silva et al. (2011a) resulting in the proposal to include Markiana nigripinnis in the subfamily Stevardiinae based mainly on features of the process of spermiogenesis shared by this species and other members of the subfamily. Quagio-Grassiotto et al. (2012) similarly found unique derived features in the spermiogenesis and spermatozoa morphology supporting a close relationship between Hollandichthys and Rachoviscus (Characidae).

\section{Acknowledgments}

We thank the Electron Microscopy Laboratory of IBBUNESP for allowing the use of their facilities. We also thank Osvaldo T. Oyakawa (MZUSP) for permission to use the facilities and to examine specimens from the ichthyological collection of the Museu de Zoologia da Universidade de São Paulo (MZUSP) and Mark Sabaj Pérez (ANSP) for the donation of gonadal tissues of various species. This study is part of a $\mathrm{PhD}$. project by the first author supported by FAPESP (Fundação de Amparo à Pesquisa do Estado de São Paulo Grant n 2010/01626-2).

\section{Literature Cited}

Baicere-Silva, C. M., R. C. Benine \& I. Quagio-Grassiotto. 2011a. Markiana nigripinnis (Perugia, 1891) as a putative member of the subfamily Stevardiinae (Characiformes: Characidae): spermatic evidence. Neotropical Ichthyology, 9: 371-376. 
Baicere-Silva, C. M., K. M. Ferreira, L. R. Malabarba, R. C. Benine \& I. Quagio-Grassiotto. 2011b. Spermatic characteristics and sperm evolution on the subfamily Stevardiinae (Ostariophysi: Characiformes: Characidae). Neotropical Ichthyology, 9: 377392.

Burns, J. R., I. Quagio-Grassiotto \& B. G. M. Jamieson. 2009. Ultrastructure of spermatozoa: Ostariophysi. Pp. 287-388. In: Jamieson, B. G. M. (Ed.). Reproductive biology and phylogeny of fish (Agnatha and Osteichthyes). Enfield, Science Publishers.

Ferreira, K. M., N. A. Menezes \& I. Quagio-Grassiotto. 2011. A new genus and two new species of Stevardiinae (Characiformes: Characidae) with a hypothesis on their relationships based on morphological and histological data. Neotropical Ichthyology, 9: 281-298.

Javonillo, R., J. R. Burns \& S. H. Weitzman. 2007. Reproductive morphology of Brittanichthys axelrodi (Teleostei: Characidae), a miniature inseminating fish from South America. Journal of Morphology, 268: 23-32.

Matos, E., P. Matos, L. Corral \& C. Azevedo. 2000. Estrutura fina do espermatozóide de Acestrorhynchus falcatus Bloch (Teleostei, Characidae) da região norte do Brasil. Revista Brasileira de Zoologia, 17: 747-751.

Mattei, X. 1970. Spermiogenése des poisson. Pp. 57-72. In: Baccetti, B. (Ed.). Comparative Spermatology. New York, Academic Press.

Netto-Ferreira, A. L. 2010. Revisão taxonômica e relações interespecíficas de Lebiasininae (Ostariophysi: Characiformes: Lebiasinidae). Unpublished Ph.D. Dissertation, Universidade de São Paulo, São Paulo, Brazil, 443p. Available from http:// www.teses.usp.br/teses/disponiveis/41/41133/tde-02022011165808/pt-br.php (accessed 25 Jan 2013).

Netto-Ferreira, A. L., 2012. Three new species of Lebiasina (Characiformes: Lebiasinidae) from the Brazilian Shield border at Serra do Cachimbo, Pará, Brazil. Neotropical Ichthyology, 10: 487-498.
Netto-Ferreira, A. L., O. T. Oyakawa, J. Zuanon \& J. C. Nolasco. 2011. Lebiasina yepezi, a new Lebiasininae (Characiformes: Lebiasinidae) from the Serra Parima-Tapirapecó mountains. Neotropical Ichthyology, 9: 767-775.

Oliveira, C. L. C., J. R. Burns, L. R. Malabarba \& S. H. Weitzman. 2008. Sperm ultrastructure in the inseminating Macropsobrycon uruguayanae (Teleostei: Characidae: Cheirodontinae). Journal of Morphology, 269: 691-697.

Quagio-Grassiotto, I. \& C. Oliveira. 2008. Sperm ultrastructure and a new type of spermiogenesis in two species of Pimelodidae, with a comparative review of sperm ultrastructure in Siluriformes (Teleostei: Ostariophysi). Zoologischer Anzeiger - A Journal of Comparative Zoology, 247: 55-66.

Quagio-Grassioto, I., L. R. Malabarba, M. A. Azevedo, J. R. Burns, C. M. Baicere-Silva \& R. Quevedo. 2012. Unique derived features in spermiogenesis and sperm morphology supporting a close relationship between the species of Hollandichthys and Rachoviscus (Characiformes: Characidae). Copeia, 2012: 609625.

Santana, J. C. O., C. M. Baicere-Silva, P. Gusmão-Pompiani, R. C. Benine \& I. Quagio-Grassiotto. 2013. An assessment approach for application of spermatic data in phylogenetic analyses: within the genus Moenkhausia Eigenmann 1903 (Characiformes: Characidae). Acta Zoologica (Stockholm), 94: 335-354.

Weitzman, M. \& S. H. Weitzman. 2003. Family Lebiasinidae. Pp. 241-250. In: Reis, R. E., S. O. Kullander \& C. J. Ferraris, Jr. (Eds.). Check list of the freshwater fishes of South and Central America. Porto Alegre, Edipucrs.

Submitted February 9, 2013 Accepted June 11, 2013 by George Mattox Published September 30, 2013 